\title{
A POSITION ON THE ISLAMIC CONCEPT OF CITIZENSHIP AND MUSLIM MINORITIES
}

\author{
Ahmet Akgündüz*
}

\begin{abstract}
This article offers an individual scholar's interpretation of the concept of citizenship and Muslim minorities from the perspective of Islamic law. The issues to be discussed are: 1. The classical Islamic legal view of a 'division' of the world and its affects on these concepts. Can we put aside these concepts? Are European countries today still to be considered dāral-harb or dāral-kufr or rather dāral-'ahd or dār al-amān? 2. What is the meaning of 'citizenship' and 'religious minorities' in a Muslim territory? 3. Are Muslims permitted to accept 'residence permits' and citizenship in non-Muslim countries? And finally 4. Should Muslims who live in European countries be referred to as 'minorities' or 'citizens'?
\end{abstract}

\section{Introduction}

Many non-Muslims, as well as their Muslim neighbours, have a desire to live together in peace as citizens of the same country. However, all too often the situation runs against all expectations. On the one hand, Muslims themselves often do not know the basic rules of Islamic law and conduct, which should be practised in Western European countries where many of them have been living for decades. This has resulted in misunderstandings, various issues, and wrong approaches toward non-Muslim communities and their style of life. On the other hand, there are misunderstandings regarding what some people refer to as the supposedly 'conflicting relationship' between Islamic rules and the domestic laws, regulations and traditions of Europe. In the view of the author, Western European states - as felt through the realities of the integration policies involved - generally interpret the integration of Muslims as abandoning their cultures, faith, and the basic principles of their religion in favour of European norms and values. In the light of this scenario, the concept of citizenship and the situation of Muslim minorities appear to be the most important controversial points. Some European countries have been paying attention to these subjects by way of academic research. ${ }^{1}$

* Professor Dr Ahmet Akgündüz is the Rector of the Islamic University of Rotterdam, the Netherlands.

1. WRR [Wetenschappelijke Raad voor het Regeringsbeleid], Identificatie met Nederland (Amsterdam: Amsterdam University Press, 2007); T. Choudhury (ed.), Muslims in the UK: Policies for Engaged Citizens (Budapest: Open Society Institute, 2004). 


\section{The Classical Islamic Legal 'Division' of the World into 'Muslim' and 'Non-Muslim' and its Effects}

To say it right at the beginning, there appears to be no explicit sacred text (nașs) - neither from the Qur'ān nor the Sunnah - about such a 'division'. However, in the past, the vast majority of Muslim scholars of the Sunnite as well as Shi'ite legal schools were in agreement about the existence of such a division. There were only some minor conflicts between the Hanafīs and other schools about the case of Muslim territory (dār al-islām) becoming dār al-kufr (non-Muslim territory). ${ }^{2}$ As a Muslim state, the Ottoman Empire had been adhering to and implementing this division until 1868. In this year, a new regulation about citizenship in the Ottoman Empire was introduced under the title of Tabi iyet-i Osmāniye Kānūnnāmesi. We shall explain this concept later on. ${ }^{3}$

Today, some modern scholars, among them Tariq Ramadan, are deliberately putting aside these concepts, considering them 'old-fashioned' terms from the period of classical medieval jurisprudence (fiqh). However, such an approach would also neglect certain rather basic Islamic legal principles, on which such a 'division' is usually supposed to be based. Among the particularly tricky legal issues in this regard would be the law of inheritance, for instance. ${ }^{4}$

After these preliminary considerations, we can say that Muslim scholars of the past have indeed 'divided' the world into distinct territories:

1. The 'Abode of Islam' or dār al-islām: This comprises a territory in its entirety in which the law of Islam ( $\operatorname{shari}^{\prime} a h$ ) prevails. Its unity resides in the community of the faith, the unity of the law and the guarantees assured thereby to the residents of dār al-islām, thus defining its Islamic identity. ${ }^{5}$

2. The 'Abode of Disbelief' ( $d \bar{a} r$ al-kufr), i.e. the territory of the non-Muslims: Some scholars referred to this also as dār-al-harb, literally 'The Abode of War'. Strictly speaking, however, such a designation is incorrect as the term dār-alharb would only be applicable should that state be at war with a Muslim country. However, according to traditional Islamic legal thought, non-Muslim countries

2. 'Abd al-Karīm Zaydān, Ahkām al-dhimmiyyīn wa'l- musta'man̄̄n (Beirut: Mu'assasat al-Risālah, 1976), 20-1; Muḥammad b. Aḥmad al-Sarakhsī, Sharh al-siyar al-kabīr, 4 vols (Cairo: Ma‘had al-Makhțūțāt, 1971), 4: 302 and 320.

3. Halil Cin and Ahmet Akgündüz, Türk hukuk tarihi [Turkish legal history], 2 vols (Konya: Selçuk Üniversitesi Yayınları, 1996), 2: 352; Rehber-i mu ämalāt [Guide to Transactions] (Istanbul, 1331 A.H./1912-13): 116-25.

4. Sayyid Sharīf Jurjān̄̄, Sharh-i sirājïyyah (Istanbul, 1322 A.H./1904), 12-14; Cin and Akgündüz, Türk hukuk tarihi, 2: 141.

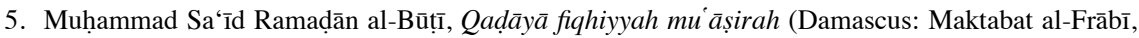
1991), 1: 181-3; Zaydān, Aḥkām al-dhimmiyyīn, 18-20; al-Sarakhsī, Sharh al-siyar al-kabīr, 3: 81 . 
(dār al-kufr) can be subdivided into two groups. Only here could the term $d \bar{a} r$ al-harb come into the picture:

(a) Dār-al-harb: This term refers here to the whole territory where Muslims have no authority or political power whatsoever and where there is war going on between such a country and Muslims, be it a Muslim state or a Muslim community living under non-Muslim occupation. In line with such a line of thought, the conflict between Israel and the Palestinians would be considered a 'war' and Israel would be automatically dār alharb. However, the case of the Muslim Turkish community living in various European countries, for instance, differs as there is an absence of a war-like situation. ${ }^{6}$ They are thus living in a dār al- $a$ ahd.

(b) Dār al-'ahd, the 'abode of truce', or dār al-amān (lit. 'abode of peace'): This refers to the whole territory where the Muslims have no authority or political power, where, however, there is peace between non-Muslims and Muslims. Muslim jurists considered this territory as some sort of 'intermediate' territory between dār al-islām and dār al-kufr. Some scholars, among them al-Māwardī (d. 1058), stated that those lands which pass into the hands of the Muslims by agreement are called $d \bar{a} r$ al-ahd, referring to some sort of 'mutual defence treaty' between the Islamic government and the non-Muslim inhabitants. However, Ramaḍan al-Būṭi states that if there is no war between a Muslim state and a nonMuslim state, then the non-Muslim country would be considered $d \bar{a} r$ al-amān, an 'abode of peace'. Although it is a territory where Muslims have no authority or political power whatsoever, there is nevertheless also no war between it and the Muslims. Rather there is a treaty ( $a h d$ ) between them.

In line with such a view, Western Europe, which features a large Muslim community - including the Netherlands, where the author of this article resides - would be dār al-amān or dār al- ahd, because there is no warfare between Muslims and these countries and there are various kinds of agreements between Muslim countries and European countries. Decades ago, many Muslims came to Europe in order to work or study, based on international treaties - which had been signed by Muslim countries. They were given a visa, therefore the existence of Muslims in those countries could be considered as based on 'ahd or 'treaty'. Muslims are thus not to be considered living in a dār al-harb or 'abode of war' setting. This is because (i) there is no war with the non-Muslims, (ii) there

6. Al-Būṭī, Qadāyāâ, 1: 183; 'Abu'l-Ḥasan 'Alī b. Muhammad al-Māwardī, 'Al-Ahkam al-sulțāniyyah wa'l-walāyāt al-dīniyyah (Cairo, 1298 A.H./1880-81), 133, 151, 166; Zaydān, Aḥkām aldhimmiyyīn, 18-20. 
are treaties between Muslims and them which ought to be respected, and (iii) Muslims have entered those countries based on those treaties. ${ }^{7}$ We can also say similar with regard to individual 'covenants' between a Muslim and a Western state: Through his obligations to which he commits when he is issued his visa, he must not create an issue in terms of public order. Such an attitude from his part would also be in line with the legal stipulations of Islam and could well be applied to all Muslim communities living in a non-Muslim country. Muslims thus ought to fulfil their obligations and must be obedient to the law of the land - laws even toward 'infidels', based on the qur'ānic command: "O you who believe! Fulfil [all] obligations" (5:1).

(c) The third category of the 'Abode of Disbelief' (dār al-kufr) is the 'Abode of Proclamation [of Islam]' or dāral-da'wah. This concept has been later developed by some scholars in order to formulate a new form of the relationship between Muslims and the non-Muslim West. However, this term indicates clearly a missionary aim and may frighten non-Muslims. Certainly, 'missionary activities' from the part of the Muslims have to be based on peaceful and rational methods. 'Legally' speaking, however, there would be no difference between dār al-amān or dār al-'ahd and this concept. ${ }^{8}$

\section{The Meaning of 'Citizenship' and 'Religious Minorities' in Muslim Territory}

In Islamic law, people are 'distinguished' from each other by their religion. That is why in Islam the term ummah ('community'), viz. the followers of the same religion, rose to the agenda in place of concepts such as 'country' and 'nation' which became more prominent in the West. Under the Anatolian Rum Seljuks and early Ottomans, the ra'iyyah (lit. 'the flock', pl. ra' $\bar{a} y \bar{a}$ ), which referred to taxpaying 'citizens' or 'subjects' (in contrast to the ruling military class), was therefore divided into Muslims and non-Muslims. In the case of the Anatolian heartland of those two empires, Greeks and Armenians were mostly Christians, whereas Turks happened to be followers of Islam. In the cause of the Ottoman expansion in Southeast Europe, aside from the Jews, even more ethnic Greek and Slavonic and other Christians became part of the ra iyyah.

7. Faysal Mawlawī, Al-Usus al-shar 'iyyah li'l- 'alāqāt bayn al-muslimīn wa-ghayr al-muslimīn (The Principles of the Religious Law Concerning the Relations Between Muslims and Non-Muslims) (Paris and Beirut: Dār al-Irshād al-Islāmiyyah, 1987), 102-4.

8. W.A.R. Shadid and P.S. van Koningsveld, Religious Freedom and the Position of Islam in Western Europe (Kampen: Kok Pharos, 1995). 
Accordingly, in Ottoman law those who lived within the confines of a Muslimruled country were 'classified' into three groups, based on their religion and the circumstances under which their former (non-Muslim homeland) had been subjugated to Ottoman rule:

1. Muslims are natural citizens in the dār al-islām and non-Muslim subjects are minorities.

2. Dhimmīs (non-Muslim subjects), viz. those who 'agreed' to live under the sovereignty of a Muslim state - though being non-Muslims, in particular 'People of the Book', i.e. Christians and Jews - with a 'contract' of dhimmah (duty of tribute and obedience owed to the Muslim state by a non-Muslim subject) and who had the right of permanent residence in an Islamic country.

3. Musta'mans, i.e. foreign non-Muslims, such as traders, mariners, and diplomats, that were allowed to enter and dwell in a Muslim country temporarily. This category was considered distinct from the dhimmī group. Nonetheless, musta'mans, were not charged with the liabilities of the privilege of permanent residence, for they merely held the right of temporary residence in a Muslim country.

After the above brief definition of the term 'minority', let us now proceed to the rights granted to religious minorities under Ottoman rule. In both the Seljuk and Ottoman empires the rights and privileges granted to Muslims were also granted to the non-Muslim citizens, called dhimmīs, with some exceptions. The allegation from the part of mostly European (but, unfortunately, also modern Turkish) scholars that rights and freedoms firstly began to be granted to non-Muslims with the firmāns (imperial edicts) of the nineteenth-century Tanžimāt or reform period would be in congruence with the facts. In the view of this writer, Muslim Turkish states, such as those of the Ottomans and Seljuks, always adopted and applied in principle a policy that could be seen as well in line with the hadith which says: "Those rights granted to us are also granted to them [i.e., the non-Muslims]; and those tasks charged upon us are also charged upon them.",

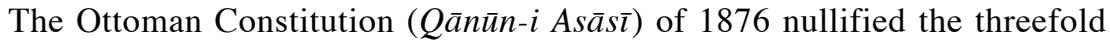
division of the subjects into Muslims, dhimmīs and musta'mans and regarded all of the first two elements equally as 'citizens', making the Ottoman state also de jure a multicultural entity - after centuries of Turkish-Muslim dominance. The supranational concept of a 'Nation of Islam' or ummah was thus replaced with that

9. "Legal Reforms", Turkish Prime Ministerial Ottoman Archives, YEE, no. 14-1540, p. 4 ff.; 'Alā' al-Dīn Abū Bakr b. Mas'ūd al-Kāshānī al-Hanafī, Kitāb badā’i al-șanā 'i’ fì tartīb al-sharā'i’, 7 vols (Beirut: Dār al-Kitāb al-'Arabī, 1982, 2nd ed.), 7: 100; Taqvīm al-Vaqā’̄ [Ottoman Official Gazette], no. 1044 (1247 A.H./1831); Ahmed Refik, XII. asr-ı hicri'de Istanbul hayatı (Istanbul: Enderun Kitabevi, 1988), 53-4, 83-4, 157, 105, 227 ff.; Zaydān, Aḥkām al-dhimmiyyīn, 10 ff., 95 ff.; Cin and Akgündüz, Türk hukuk tarihi, 2: $310 \mathrm{ff}$. 
of an 'Ottoman Nation'. Already in 1868, a law, the already mentioned Tabi iyet- $i$ 'Osmāniye Kānūnnāmesi, had referred to only two categories: teb'a, 'Ottoman citizens', and $e c n e b \bar{l}$ 'foreigners'. In 1864, that was preceded by the participation of members from the minorities in representative urban councils. Subsequently, non-Muslim minorities were also accepted as members of courts of law, until they were ultimately, in 1879, also employed in the newly founded 'Ministry of Justice and Madhhabs' (Islamic legal rites). The term jizyah, the quasi 'poll-tax' of the olden days - seen as a token of being subjugated to an Islamic state - was at about the same time 'reinterpreted' as the service of non-Muslims in the Ottoman armed forces, which until that time had been closed to dhimmīs. ${ }^{10}$

\section{Muslims as 'Residents' and 'Citizens' of Non-Muslim Countries?}

From the perspective of Islamic law, when discussing the issue of Muslims living in a non-Muslim country, we come across the following two terms: iqāmah (staying permit) and istitān or tajannus (citizenship in non-Muslim countries).

\section{Iqāmah (staying permit)}

The first subject is the problem of the permissibility of staying, for the purpose of work, study, commerce, etc., in a land ruled by non-Muslims. Based on the Qur'ān and rulings of the Prophet, a famous maxim of Islamic law says that everything on this earth is lawful ('permissible', mubāh in Arabic), that is, it is 'optional', unless it is clearly 'forbidden' (i.e. made or declared harām). Therefore, one could describe mubāh as 'neutral' which means that such a thing is neither 'obligatory' nor 'forbidden'. The shari 'ah has kept otherwise silent about it and did not outline its rule, and one could well argue that whatever the shari ah disregarded is mubāhl. It has been reported that the Prophet once said: "Truly, Allāh has commanded some obligations, hence do not neglect them; and He prohibited certain matters, hence do not violate them; and He determined certain limits, hence do not transgress them and He condoned certain matters out of mercy, not forgetfulness, hence do not search for them." In another narration, he said: "And that which He kept silent about is a condonation (permission)". The adoption of rules and laws which have not been mentioned by the shari ah and which the shari ah did not mention by any prohibition is part of the mubāh. Therefore, in the view of this writer, a Muslim would be allowed to choose any part of the world as his abode unless he encounters a prohibition by the sharī ah. The Qur'ān stipulates: "It is He Who has made the earth

10. Turkish Prime Ministerial Ottoman Archives, YEE, no. 14-1540,p. 23; Ziyaeddin Fahri Fındıkoğlu Fındıkoğlu, Tanzimatta içtimaî hayat (Social Life During the Tanzimat Period) (Istanbul: Maarif Matbaası, 1940), 619; Ahmet Cevdet Paşa, Tezakir-i Cevdet, ed. Cavit Baysun, 12 vols (Ankara: TTK, 1986), 1: 68 ff.; Cin and Akgündüz, Türk hukuk tarihi, 2: 336-7. 
manageable for you, so traverse ye through its tracts and enjoy of the sustenance which He furnishes: but unto Him is the Resurrection."11

There are other legally sanctioned reasons that appear to support the right of staying in non-Muslim countries, such as commerce, search for a job, studying at universities. Some scholars even mentioned the preaching of Islam as another 'legal reason' for this. Moreover, the Prophet has advised his Companions to travel to other parts of the world for commerce, work or study. In the year $7 \mathrm{AH}$ (614-15 $\mathrm{CE})$, twelve male and twelve female Companions - Muslims who had converted back in Mecca - migrated to Ethiopia, seeking refuge from persecution. They were allowed by the country's Christian king to stay there in peace and security for as long as they wished.

We do, however, encounter also two principles of Islamic jurisprudence that could be seen as obstacles to iqāmah:

The first of them is sadd al-dharā ' $\bar{\imath}$, which means 'the blocking of the means', i.e. toward undesirable ends, in other words, the impermissibility of what is likely to lead to unlawful (harām) acts and circumstances. This is thus an extension of the general legal principle, according to which that what leads to harām is harām in itself - in analogy to the premise "all what leads to the 'obligatory' (wajjib) is 'obligatory', and what leads to the 'permitted' (mubāh) is 'permitted"'. If the staying in non-Muslim countries would cause such 'undesirable ends' in the morals etc. of family members or about their faith and practice, this should be taken into serious consideration by Muslims. ${ }^{12}$

The second quasi 'obstacle' would be the impermissibility of staying in what is considered dār al-mafāsid (lit. 'the abode of corruption/prevention' [i.e. from the practising of Islam]): The underlying principle of this concept states that "whatever leads to unlawful (harām) practices is unlawful". If the stay in nonMuslim countries would lead to unlawful practice etc., a Muslim would have to reconsider this situation. These 'unlawful things' may involve the 'purity' of faith or deeds or words. The Qur'ān states: "When angels take the souls of those who die in sin against their souls, they say: 'In what [plight] were ye?' They reply: 'Weak and oppressed were we in the earth.' They say: 'Was not the earth of Allāh spacious enough for you to move yourselves away [from evil]?' Such men will find their abode in Hell - What an evil refuge!"13

In summarising what has been said above, we can say that the opinions of Muslim scholars on the permissibility of Muslims staying in non-Muslim countries can fall into two groups:

11. Qur'ān 67:15.

12. Muhammad b. 'Alī Shawkānī, Irshād al-fuhūl (Cairo: Dār al-Quṭb, 1992), 2: 279-83.

13. Qur'ān 4:97; Muḥammad b. Bahādur al-Zarkashī, Al-Baḥr al-muhīt fì uṣūl al-fiqh (Kuwait: Wizārat al-Awqāf wa'l-Shu'ūn al-Islāmiyyah, 1992), 5: 76-81. 
(a) Most of them (jumhūr) permit the staying in non-Muslim countries in terms of iqāmah (staying permit), as outlined above. However, theirs is a 'provisional' acceptance. A Muslim individual should gauge between the two (positive and negative) possibilities sanctioned by Islamic law and decide for himself. Based on the Qur'ān and the Sunnah of the Prophet, however, Islamic law says that everything on this earth is 'lawful' (permissible, mubāhh), unless nothing else is explicitly stated.

(b) The medieval Andalusian scholar Ibn Hazm (d. 1064) disagreed with most of his colleagues, saying that such a stay would be completely harām, with the exception of two situations: first, in the case of $j i h \bar{a} d$ and second for conveying the letter of a Muslim ruler, i.e. during diplomatic missions to non-Muslim countries. In this context, it is significant that Ibn Hazm is using the term $d \bar{a} r$ $a l-h a r b$ and refrains from expressions such as dāral-amān or dāral-'ahd. ${ }^{14}$

\section{Tajannus or istitān (citizenship) in non-Muslim countries}

Here we have to consider the fact that these two terms (or similar expressions) do not exist in the works of classical medieval Islamic jurisprudence. However, Muslim jurists have discussed the underlying issue. Today perhaps about one third of the world's Muslims are living in a minority situation. From this perspective, the very discussion of the acceptability of residing in a non-Muslim country is nothing less than an anachronism and an anomaly. ${ }^{15}$ The main problem about citizenship is muwālah, a term which originally means 'friendship' (in the sense of 'clientage'), but used here in the sense of 'support' for a non-Muslim state and submitting to its legal system which is contradictory to Islam. The Qur'ān says:

Let not the believers take the disbelievers as awliyā' [i.e., supporters, helpers, etc.] instead of the believers [i.e. Muslims], and whoever does that will never be helped by Allāh in any way, except if you indeed fear a danger from them. And Allāh warns you against Himself [i.e., His punishment], and to Allāh is the final return. Say [O Muhammad]: "Whether you hide what is in your breasts or reveal it, Allāh knows it, and He knows what is in the heavens and what is in the earth. And Allāh is able to do all things." ${ }^{\prime 16}$

This passage was revealed concerning a group of Muslims who had Jewish friends to whom they were also offering muwālah. Some of the other Companions (of the Prophet, șạ̄abah) said to those Muslims: "Keep away from those Jews and beware

14. Al-Būṭī, Qaḍāyāa 1: 183-98; Mawlawī, Al-Usus al-shar 'iyyah, 102-4; Muḥammad b. Aḥmad al-Qurțub̄i, Al-Jāmi“ li-ahkāmm al-Qur'ān (Beirut: Dār al-Fikr, 1987), 5: 348.

15. Wasif Shadid and Sjoerd van Koningsveld, "Loyalty to a Non-Muslim Government: An Analysis of Islamic Normative Discussions and of the Views of Some Contemporary Islamicists", in: Wasif Shadid and Sjoerd van Koningsveld (eds), Political Participation and Identities of Muslims in Non-Muslim States (Kampen: Kok Pharos, 1996), 84-115.

16. Qur'ān 3:28-9. 
of their friendship for they could seduce you away from your religion and guide you astray after you have believed." However, this group of Muslims disregarded their advice and remained loyal to their Jewish friends. It is within this context that the verse "Let not the believers take the disbelievers as awliya ", "was revealed.

As a matter of fact, Muslim scholars appear to be divided on this issue. Some of them object totally to any kind of acceptance of citizenship in any form granted to Muslims by a non-Muslim country, except under obligation. Hanbalī scholars in particular had been against the idea of Muslim 'citizenship'. As we have mentioned, the Zāhirī Ibn Hazm, too, was one of the most outspoken critics and recently the imām of the Grand Mosque (Masjid al-Harām) in Mecca, Muhammad b. 'AbdAllāh b. Sabīl, too, has written an article which summarises the various fatwās and criticisms on the 'citizenship' debate among Muslim scholars.

Of particular concern to the critics appears to be the historical occurrence of an even more drastic change when Muslim governments were totally replaced (by force) by a non-Muslim government or subjected to it. This was often the case during the colonial era. Almost every country with a Muslim majority was affected by it. This new situation resulted in a stream of discussions concerning the relations between Muslim subjects and their respective non-Muslim governments. Some of these historical events - especially the fate of the Andalusian Muslims - had reflected in discussions during the colonial period and even in recent works by religious scholars regarding the position of Muslim minorities in contemporary Western Europe.

First of all, there was the problem - similar to that of the Andalusian and Bosnian Muslims - of whether one was allowed to give up fighting and to remain living under non-Muslim rule, or whether one was obliged to continue the armed resistance and/ or to immigrate to an area governed by a Muslim ruler. The contemporary historian al-Mannūnī mentions no less than five works written by Moroccan scholars on this subject during the first decades of the twentieth century. There are also several fatwās from Indonesia discussing the same complex of problems related to the expansion of Dutch colonial rule. In Egypt, the nineteenth-century Mālikī scholar of Al-Azhar, 'Abd al-Rahmān 'Illaysh also wrote an extensive treatise about this problem. He, among others, referred to fatwās of the Moroccan scholar al-Wansharīsī about the position of Muslims who had remained in Christian Spain after the fall of Granada in 1492. Al-Wansharīsī had urged the Andalusian Muslims under Christian rule to immigrate to the 'abode of Islam' ${ }^{17}$

Here it can only be mentioned in passing that the close interaction between (nonMuslim) Europeans and the Muslim inhabitants of the colonies induced a long series of discussions among the Islamic religious scholars about the issue of 'assimilation

17. Shadid and van Koningsveld, "Loyalty", 84-115; Muhammad b. 'Abd-Allāh, "Al-Tajannus bijinsiyyah ghayr islāmiyyah”, Majallat al-mujamma’ al-fiqh al-islāmī 2, no. 4 (2005), 107-75. 
to the infidels'. Closely related to this 'assimilation' is the issue of the adoption of citizenship and nationality of the colonising state. This problem arose in only a few of the colonised countries, especially in the Maghreb which was facing France. The European concept of nationality and nationhood was alien to the classical Islamic legal tradition. However, since the second half of the nineteenth century, and especially since the Law of Ottoman Citizenship of 1869, it was gradually penetrating into the political and legal systems of the Muslim world. Notwithstanding occasional conflicts, this penetration can be seen as a mere process of translating the existing social and political realities into a new legal terminology.

However, a completely new dimension was added in Tunisia and Algeria, when the French authorities introduced laws of naturalisation in 1923 and 1927, respectively. These laws offered French nationality and full rights of French citizenship to Tunisian and Algerian Muslims who accepted French civil law instead of Islamic law. This measure met with fierce resistance from the side of many Muslim scholars. The scholars of the Zaytouna in Tunis, one of Islam's oldest universities, issued a fatwa which qualified the person who adopted French citizenship under the said law as an apostate. Their view was supported by similar fatwās issued by scholars of Cairo's Al-Azhar and other scholars in Egypt, among them Shaykh Shākir, the former vice-rector ( $w a k \bar{l} l$ ) of Al-Azhar, Rashīd Riḍā, editor of the journal Al-Manār, Shaykh 'Alī Surūr al-Zankalūnī, and Shaykh Yūsuf al-Rajawī. ${ }^{18}$

By virtue of those views, a Muslim in the Tunisian town of Bizerta who had accepted French nationality was not buried in the graveyard of the Muslims. His apostasy was confirmed by the local muftī, Shaykh 'Alī al-Sharīf. Consequently, he was buried by the French in the section which was reserved in the graveyard of the Muslims for foreigners and unidentified people. Other scholars, however, merely stated that he had committed a grave sin. The French stipulated the adoption of French citizenship as a condition for anyone who wanted to acquire a position of some importance in colonial society. This was part of the French assimilation policy. The arguments which were forwarded by the scholars who condemned the acquisition of French nationality during the colonial era as an act of apostasy have been repeated in several recent discussions published in France and the Netherlands concerning the subject of naturalisation within the wider context of the integration of Muslim immigrants into Western European societies. ${ }^{19}$

A second group of Muslim scholars - among them Ramaḍān al-Būṭi and 'Abd al-Karīm Zaydān - disagree and have refrained from giving fatwās on the issue citizenship. However, they have explained that there may be some obligatory

18. Shadid and van Koningsveld, "Loyalty", 84-115; Muhammad b. 'Abd-Allāh, "Al-Tajannus", 107-75 (contains the full text of Rashīd Riḍā's fatwā).

19. Shadid and van Koningsveld, "Loyalty", 84-115; Muḥammad b. 'Abd-Allāh, "Al-Tajannus", $107-75$. 
situations for Muslim in which they would be able to accept the citizenship of non-Muslim states. The scholars involved have based their assertions on the legal concept of darürah, literally 'necessity, need, requisite, essential' etc. The technical meaning is amounts to something that is essential, especially basic requirements and circumstances that create a need or an obligation. Practically speaking, that would, for instance, mean that in case a non-Muslim country does not issue a staying permit, a Muslim may be 'obliged' to accept citizenship instead. One might also think of the case in which a Muslim would be prevented to exercise certain rights and freedoms unless he or she becomes a citizen. With regard to those scenarios, some scholars have given fatwās in favour of the acceptance of citizenship..$^{20}$

Another group of scholars, however, does allow for citizenship in non-Muslim countries. Among them are Shi' ite as well as Sunnite scholars. According to them, Islam permits Muslims to accept 'protection' of their life, property, and freedom by non-Muslim rulers and their political systems, that is to say the granting of 'asylum' of various kinds - and ultimately, citizenship. Muslims who find themselves in such a situation are thus allowed to pay taxes to a non-Islamic state. They are also obliged to abide by the laws of that state as long as such obedience would not conflict with their 'loyalty to Islam and the ummah'. Active military duty in a non-Muslim army during an armed conflict with a Muslim country, for instance, could cause 'identity problems' for them would they choose to become citizens of a non-Muslim nation. Such a 'conflict of interests' could also arise would they offer material or moral assistance to those who are engaged in a 'struggle for Islam' abroad.

The preeminent Twelver Shi'ite scholar of our times, Grand Ayatollah Sayyid 'Al̄̄ al-Husaynī al-Sīstānī (b. 1930), who is based in Najaf (Iraq), appears to see in issued visas a kind of arrangement that implies 'security' (amān) for the Muslims to enter and reside in a non-Muslim country for the precise time stipulated by the visa. Under all circumstances, Muslims must obey local law as they are living in the 'abode of truth' (dār al-'ahd) mentioned earlier. ${ }^{21}$ To give a more down-to-earth example: When this writer arrived in the Netherlands (where he has been residing since), he was issued a visa and had to sign a certain document. The issuance of the visa and the signing of the document can be considered as some sort of 'legally binding contract', a kind of 'mini treaty' of 'peace' (sulh). The author agreed upon entering the Netherlands to obey the laws of that country for the duration of his stay and to follow the rules and regulations. It was a contractual agreement that is binding even according to Islamic law. However, the relationship between the

20. Muhammad Shajālī al-Nayfar, "Al-Tajannus bi-jinsiyyah ghayr islāmiyyah”, Majallat almujamma' al-fiqh al-islāmī 2, no. 4 (2005), 178-252; al-Būṭī, Qadāyā , 1: 198-204.

21. Sayyid 'Alī al-Ḥusaynī Sīstānī, Minhāj al-șāliḥ̄nn:Fatāwā (Beirut: Dār al-Mu'arrikh al-'Arabī, 1993), passim. 
Muslims living in the Netherlands and the Dutch should not only be considered a contractual relationship of peace, but also a relationship based on dialogue and mutual respect, thus a relationship of 'giving and taking'. In the following, some points that are closely related to this view shall be elaborated further.

1. The verses of Qur'ān relating to walā should be reconsidered. Bediuzzaman Said Nursi (1878-1960) has opened new avenues for interpreting the qur'ānic verse 5:51 which deals with interfaith relations and runs as follows:

O ye who believe! Take not the Jews and the Christians for your friends and protectors: They are but friends and protectors to each other. And he amongst you that turns to them [for friendship] is of them. Verily Allah guideth not a people unjust. ${ }^{22}$

Only some years before the beginning of the First World War, around 1910, Said Nursi was questioned concerning his desire to build relations of friendship with Christians. He was confronted with the restrictive interpretation that some Muslims had placed on this qur'ānic verse. ${ }^{23}$ In the light of this verse, can we maintain that Muslims and non-Muslims should build ties of friendship? The answer is "Yes", because the qur' anic proscription is not general but absolute and, as such, can be restricted. "Time", Nursi said, "is a great interpreter; if it determines its limits, it cannot be gainsaid. That is, when a matter becomes clear in the course of time, one cannot object to it. Moreover, if the judgment is based on derived evidence, the source of the derivation shows the reason for the judgment." ${ }^{24}$ In applying this principle to the interpretation of this verse, we can hold that the prohibition from friendship with Jews and Christians is effective only when such relations would reflect solely the Jewish or Christian side while neglecting the Muslim aspect. However, we may conclude, just as not all of the characteristics of an individual Muslim necessarily reflect the teaching of Islam, so also, not all of the qualities of individual Jews or Christians reflect 'unbelief' (kufr). If Muslims find in a Jew or Christian qualities that are in agreement with the Islamic teachings, they should consider those qualities praiseworthy. It is those good qualities that form the basis for friendship with Jews and Christians. With this premise, even marriages with Jews or Christians, 'People of the Book', are principally possible from the Islamic perspective. This argument is based on the very fact that the Qur'ān (according to the interpretation of the Hanafīs) permits a Muslim man to marry a Jewish or Christian woman, presuming that he can and should love her.

22. Qur'ān 5:51.

23. Bediüzzaman Said Nursi, Munazarat. Risale-i Nur Külliyatı (Istanbul: Nesil Yayinevi, 2002), 1944.

24. Ibid. 
2. The sixtieth sürah of the Qur'ān, Al-Mumtahanah (The Examined One), can be considered a 'collection of rules' concerning Muslim relations with nonMuslims. Some verses from this chapter on this topic run as follows:

It may be that Allāh will grant love [and friendship] between you and those whom ye [now] hold as enemies. For Allah has power [over all things]; And Allāh is Oft-Forgiving, Most Merciful. Allāh forbids you not, with regard to those who fight you not for [your] Faith nor drive you out of your homes, from dealing kindly and justly with them: for Allāh loves those who are just. ${ }^{25}$

Some scholars claimed that these verses had been 'abrogated' or 'replaced' (naskh typically involves the 'replacement', ibdāl, of an earlier verse/tradition and thus its embodied ruling with a successive one). The majority of the Islamic scholars, however, did not accept that. ${ }^{26}$

It also should be remembered that all what the Prophet, during his Meccan period, asked for from the Quraysh was that they grant him the freedom to call the people to Islam. However, they would not let him do that. However, in the Netherlands (and in the rest of the European Union, for that matter) there exist no obstacles for purely religious Islamic missionary activities. There are no prohibitions as religious freedom is enshrined in the constitutions of the EU member countries. No one would be arrested or maltreated for proselytising. This fact cannot be emphasised enough as it has to do with gratitude toward the host nation, be it Muslim or non-Muslim. It is a necessary requirement and religious duty for Muslims to show respect to non-Muslims, in particular those of them who have offered Muslims hospitality in their country, by granting asylum or work and study permits, and social security benefits. Above all, Islam prohibits Muslims from showing hostility towards people who are welcoming and respectful. After all, Muslim immigrants should consider themselves guests in non-Muslim countries and respect the host country and its customs and laws.

Muslims also have to be good citizens because an excellent Muslim is also an excellent citizen in the society he lives in. This does not mean that we lose our distinction, that we become completely immersed in the dominant society to where we no longer have our own identity - that is not what we are calling to. We have to maintain those things that are particular to us as a community, but we also have to recognise that there are other things that are not particular to us but rather general to the human condition that we can partake in; and these things are not things that we should be ignorant and neglectful of but things that we should be engaged in. We have to maintain our roots - especially a deep-

25. Qur'ān 60:7-8.

26. Al-Nayfar, “Al-Tajannus”, 220-52. 
rooted faith - but at the same time we have to be open to allow others to come into that deep-rootedness as well.

3. Islamic international law has given principal attention to a state's jurisdiction to prescribe law in criminal matters. As a matter of fact, there exist a number of jurisdiction theories. The territorial theory allows for jurisdiction over persons, things, or acts that take place within the territorial boundaries of the state. Under the nationality theory, a state may prescribe law over persons or things that share its nationality. Moreover, customary international law, under the nationality theory, permits a state to exercise jurisdiction over its subjects wherever they may be located. The protective principle expands these traditional bases of jurisdiction by emphasising the effect of an offence committed outside the territory of a state and allows the exercise of jurisdiction where conduct is deemed harmful to the national interests of the forum state. Most European countries have accepted this approach, including Austria, Denmark, Finland, France, Spain, Sweden, and Greece. Thus, any state may impose liability - even on persons who are not its nationals - for conduct outside its borders that has effects and consequences within its borders that the state reprehends. In summarising, the territorial principle allows for the exercise of jurisdiction over acts occurring within a state's territory. Sunnites (especially Hanafīs) have preferred this principle.

Another theory amounts to extraterritorial jurisdiction over acts occurring within as well as outside the territory of a state. The Ja farīs (i.e. the followers of the Twelver Shi'ite school of law) seem to prefer the extraterritorial theory, which, for instance, would allow for Islamic law to be applied toward apostates even in non-Muslim countries. The majority Sunnites, however, do not believe in extraterritorial jurisdiction.

\section{Muslims Living in European Countries: 'Minorities' or 'Citizens'?}

How do we look at Muslims living in European countries; are they really 'minorities' or do we have to consider them 'citizens' in the Islamic legal sense that has just been outlined? In the following, we shall look at this issue from two perspectives:

Firstly, Muslims who have passports issued by European countries are, of course, full citizens of those states, with all rights and duties that may entail. There is thus no difference between citizens, let's say of Muslim or non-Muslim faith, or between citizens with a different ethnic background. However, in spite of those legal guarantees in all the member states of the European Union, in practice there is often a wide gap between those laudable stipulations and the way those 'new citizens' are looked at by the 'native' Europeans. 
In the daily discourse on immigration issues, the indigenous population is often referred to as autochthons, whereas its opposite - the term allochton - is used in the Netherlands and Belgium (originally in Dutch, but more and more also in French) to designate people or groups of people of foreign origin. This labelling of non-native populations is one of the complex results of migration movements and subsequent citizenship legislation, which both have become parts of the life story of immigrants. Often, even the second, third and fourth generations of migrants, that is to say people born in European countries and those who have actually obtained the European citizenships, are still included under those labels.

Some European constitutions, however, appear to be more inclusive. In Article 1 of the Dutch Constitution, for instance, we read:

All persons in the Netherlands shall be treated equally in equal circumstances. Discrimination on the grounds of religion, belief, political opinion, race, or sex or on any other grounds whatsoever shall not be permitted.

There should thus be no doubt that Muslims who have once obtained citizenship in or were born as a citizen of a European state are full citizens. As a matter of fact, however, in many cases Muslims continue to be a cultural, ethnic, and religious minority in spite of their status as citizens, be it naturalised or by birth. ${ }^{27}$

Secondly, once Muslims have been accepted legally (i.e. based on the laws of a European country) as citizens of a non-Muslim country, they should not be referred to as 'minorities'. The political traditions of the Netherlands and the United Kingdom - unlike those of France - accord respect to particularistic identities and have historically recognised ethnic and religious communities within the public sphere. While France emphasises the integration of individuals, Britain places primacy on processes of collective bargaining and collective integration. Civil society, rather than the state, develops the mechanisms of social solidarity. The political process in Britain is based not on the absolute equality of individuals, as in France, but on civil ethics, such as mutual respect and fairness. This emphasis favours pragmatic solutions accommodating the concerns of different social groups. At the same time, however, it also implies that British society is more tolerant of inequality among ethnic and religious groups on the national level. In Germany, more diversity is permitted in the public sphere than in France, and more formal organisation of religious and ethnic groups is required than in Britain. On the one hand, the German political system holds that any group forming part of German society should have a right to representation in public; if particularistic ties are recognised as part of society as a whole, this view contends, all members will maintain a stable identification with society. This, by the way, is one of the reasons for the hesitation of the German

27. Choudhury (ed.), Muslims in the UK. 
public to admit new groups: integration into German society takes usually one to two generations longer than in other European countries. On the other hand, the German system requires more systematic and centralised organisation of minority groups, in order to avoid too much heterogeneity and therefore inequality.

Generally speaking, Muslim minorities - once admitted as full citizens in a European country - cease to be minorities (of foreigners) according to the law, although they will always be a minority in terms of culture and, above all, ethnic and religious background. They should not be singled out and should not be considered second or third class citizens. After all, with the obtaining of their new citizenships, they are accorded equal rights and obligations towards their new homeland, and humanity at large.

\section{Conclusion}

In closing, it should be pointed out that there are also several circumstances with regard to the controversial issue of Muslims as citizens of a non-Muslim country that appear to stand out in favour of it - in spite of the variety of criticism from the part of Muslim scholars of past and present days:

- Most Muslim scholars have allowed citizenship and issued fatwās in this regard.

- The existence of a Muslim community of at least 20 million in western countries.

- Islamic law is not supposed to differ from one country to another.

As a matter of fact, Islamic law has developed a 'subsection' - known today as fiqh al- 'aqalliyyāt or 'Islamic law for minorities' - which addresses explicitly this issue. However, a Muslim jurist must relate to the general trends and premises of Islamic jurisprudence in order to address the specific circumstances of a specific community living in specific circumstances, where what is suitable for them may not be suitable for others. Therefore, he must not only have a strong background in the traditional Islamic legal sciences, but must also be well-versed in the fields of modern sociology, economics, politics, and international relations, as all of them have a bearing on minority communities.

'Islamic law for minorities' covers two types of Muslim minorities in Europe: (1) the 'traditional' Muslim population which has been present on the continent for centuries, such as in Bosnia and other parts of the Balkans, and (2) the immigrant communities from Muslim countries of more recent date. The purpose of fiqh al'aqalliyy $\bar{a} t$ in this understanding is thus not to 'recreate' another form of Islam, but to develop a set of methodologies that would govern a Muslim jurist's work within 
the flexibility offered by Islamic jurisprudence in order to apply it best to particular circumstances. 'Islamic law for minorities' might thus open new and progressive avenues for Muslims in the West who are facing a globalised world, without having to give up their distinctive identity.

All in all, minorities - Muslims in non-Muslim countries as well as non-Muslims in Muslim states - should have equal rights and obligations. In the view of this writer, any form of discrimination based on gender or religion is un-Islamic and fully rejected by the teachings of Islam. Yet, human deeds and behaviours should not be a reference to judge Islam (or other religions, for that matter) rashly as a whole, especially when those behaviours and actions are arbitrary and unjust. 